\title{
EPC1 Gene
}

National Cancer Institute

\section{Source}

National Cancer Institute. EPC1 Gene. NCI Thesaurus. Code C111955.

This gene plays a role in both transcriptional regulation and histone acetylation. 